\title{
THE EFFECT OF ASPECT RATIO AND VOLUME FRACTION ON MECHANICAL PROPERTIES OF STEEL FIBRE-REINFORCED OIL PALM SHELL CONCRETE
}

\author{
Soon Poh YAP, U. Johnson ALENGARAM, Mohd. Zamin JUMAAT \\ Department of Civil Engineering, Faculty of Engineering, University of Malaya, \\ 50603 Kuala Lumpur, Malaysia
}

Received 09 Dec 2012; accepted 09 Apr 2013

\begin{abstract}
The utilization of oil palm shell (OPS) as a replacement for conventional coarse aggregate produces a greener structural lightweight aggregate concrete (LWAC). Steel fibres enhance the mechanical properties of LWAC including OPS concrete (OPSC). This paper reports on the influence of the aspect ratio $(1 / \mathrm{d})$ and volume fraction $\left(\mathrm{V}_{\mathrm{f}}\right)$ of hooked end steel fibres in oil palm shell fibre-reinforced concrete (OPSFRC). The fresh and hardened concrete properties, including ultrasonic pulse velocity (UPV) and post-failure compressive strength (PFCS) of ten mixes with three each for $1 / \mathrm{d}(55,65$ and 80$)$ and $\mathrm{V}_{\mathrm{f}}(0.25 \%, 0.5 \%$ and $0.75 \%)$ are investigated. The mix with an $1 / \mathrm{d}$ of 65 produced the highest values of slump, density, and compressive strength. The enhancement in the splitting tensile strength of $83 \%$ compared to the control mix was obtained for the mix with the highest $1 / \mathrm{d}$. Generally, the increase in $\mathrm{V}_{\mathrm{f}}$ from $0.25 \%$ to $0.75 \%$ improved the mechanical properties. The UPV results indicated that all OPSFRC and PFCS of $66-70 \%$ obtained were of good quality.
\end{abstract}

Keywords: steel fibre, oil palm shell, fibre-reinforced concrete, lightweight concrete, mechanical properties.

\section{Introduction}

The recent researches for converting palm oil into biodiesel and the need for vegetable oil globally have increased the production of palm oil, especially in the palm oil producing countries, such as Indonesia and Malaysia. The production of palm oil also increases the waste from the palm oil industry; the waste includes oil palm shell (OPS), empty fruit bunches, palm oil fuel ash (POFA), fibres, palm trunks and more. Malaysian oil palm industry produced 4 million tonnes of OPS annually (Alengaram et al. 2013). The common way of handling the OPS waste is by uncontrolled dumping in open air spaces. This causes storage problems in addition to environmental pollution. In addition to that, oil palm wastes including OPS, palm trunk, palm leaves and fruit bunches are also combusted in boiler to generate power (Foo, Hameed 2009). However, this method is not widely used due to high cost to handle the residual waste, palm oil fuel ash. Compared to conventional granite aggregate, OPS are lightweight and possess good aggregate impact value (AIV) and aggregate abrasion value (Jumaat et al. 2009; Mannan, Ganapathy 2004) and hence research works have been carried out on the utilization of OPS as a coarse aggregate to replace the conventional coarse aggregate in the development of lightweight aggregate concrete (LWAC).
The replacement of natural coarse aggregate with OPS could pave the way for sustainable development as the depletion of natural resources creates an ecological imbalance (Short, Kinniburg 1978). The conversion of agricultural or industrial waste into construction materials has environmental gains, such as minimizing the extraction of natural resources and maximizing the useful life of the sanitary land-filling, etc. (Yildiz et al. 2012). The early researchers showed that LWAC could be produced by using OPS as coarse aggregate with a density and compressive strength in the range of $1700-1850 \mathrm{~kg} / \mathrm{m}^{3}$ and $5-25 \mathrm{MPa}$, respectively (Okafor 1988; Basri et al. 1999; Mannan, Ganapathy 2001, 2002, 2004). LWAC has many advantages compared to normal weight concrete (NWC). These include dead load reduction and cost savings on reinforcement, formwork, scaffolding, foundation, transport and erection; further, the improved functional and structural behaviour, such as fire resistance, heat insulation, sound absorption, frost resistance, anti-condensation properties and cyclic loading structural responses are added advantages of LWAC (Alengaram et al. 2010a; Shafigh et al. 2010). These advantages allow OPS concrete (OPSC) to be potentially used in low to moderate strength materials, such as pavements, flooring, walls, and granular filter, for water treatment (Basri et al. 1999; Alengaram et al. 2013).

Corresponding author: Johnson Alengaram

E-mail: ujohnrose@yahoo.com 
During the last decade, there have been many research works on OPSC pertaining to strength enhancement, durability and structural behaviour. The pre-treatment methods (Mannan et al. 2006), effects of curing conditions (Teo et al. 2007), and aggregate size of OPS (Alengaram et al. 2010b) are among the studies on the enhancement of the performance of OPSC. Alengaram et al. (2010a) showed that the bond property of OPSC is comparable to the NWC, while Teo et al. (2007) concluded that the bond and durability properties of OPSC are comparable to other structural lightweight concrete made of pumice and expanded polystyrene. Further, an increase in the sand content and the addition of mineral admixtures, such as silica fume (SF) and fly ash (FA), could enhance the modulus of elasticity of OPSC (Alengaram et al. 2011a). In terms of structural behaviour, OPSC showed enhanced performance in flexure and shear compared to NWC. The ductility ratio of OPSC was twice that of NWC (Alengaram et al. 2008). Alengaram et al. (2011a, 2011b) reported that the good aggregate interlock in OPSC resulted in shorter flexural and shear cracks compared to NWC.

The use of fibres on the enhancement of flexural toughness, impact resistance and related parameters is well established. The application of steel fibres in different types of concrete, such as NWC (Özcan et al. 2009), high strength concrete (Eren, Çelik 1997), lightweight concrete (Düzgün et al. 2005), ultra-high performance concrete (Habel, Gauvreau 2008) and self-compacting concrete (Deeb et al. 2012) has changed the design philosophy of reinforced concrete. Many researchers reported the effect of steel fibres on the enhancement of the characteristics, such as mechanical properties, shrinkage, freeze-thaw resistance (Atiş, Karahan 2009), modulus of rupture, deflection capacity, energy absorption (Kim et al. 2011), fatigue strength (Cachim et al. 2002), toughness (Nataraja et al. 2000), shear strength (Slater et al. 2012), torsion strength (Okay, Engin 2012), impact resistance (Nili, Afroughsabet 2010), and fire resistance (Fike, Kodur 2011). Further, studies on the effects of steel fibres in LWAC using expanded clay aggregate (Gao et al. 1997), sintered fly ash aggregate (Kayali et al. 2003) and natural pumice (Düzgün et al. 2005; Libre et al. 2011) were reported.

The significant enhancements by the addition of steel fibres provokes the use of steel fibres in LWAC includes OPSC. The enhanced properties of LWAC enable a wider range of application of the LWAC. Instead of flooring and walls, the steel fibre-reinforced OPSC can be applied in structural members, such as beams, columns or ground supported slabs. The recent work on the use of steel fibres in the OPSC (Shafigh et al. 2011) reported on steel fibres of the aspect ratio 65 only. However, no investigation has been carried out on the effect of the aspect ratio and volume fraction of OPSC. The investigation on the aspect ratio is important, as it is reported that both the aspect ratio and fibre volume have a significant effect on the of properties concrete (Gao et al. 1997). The selection of fibres is vital in optimizing the mechanical properties of OPSC. Thus, the significance of this investigation lies in the following: the effect of aspect ratio of steel fibres on OPSC and the influence of the volume fraction of each aspect ratio on OPSC.

Previous studies (Eren, Çelik 1997; Nili, Afroughsabet 2010,2012 ) indicated that silica fume can further enhance the mechanical properties, impact resistance and electrical resistivity of steel fibre reinforced concrete. In order to enhance the mechanical properties, $10 \%$ silica fume on cement weight was added as additional cementitious material. The mechanical properties of steel fibrereinforced OPSC, referred hereafter as oil palm shell fibre-reinforced concrete (OPSFRC), were studied. In addition, the ultrasonic pulse velocity (UPV) of OPSC was measured and reported. The post-failure compressive strength of OPSC was also investigated and analysed.

\section{Experimental programme}

\subsection{Materials and mix proportions}

\subsubsection{Cement and silica fume (SF)}

For all mixes, Ordinary Portland Cement (OPC) with a Blaine specific surface area and specific gravity of $335 \mathrm{~m}^{2} / \mathrm{kg}$ and 3.10 , respectively, was used. Condensed silica fume of $10 \%$ of cement weight was added as cementitious material.

\subsubsection{Aggregate}

OPS collected from the local crude palm oil mill were used as coarse aggregate. The physical properties of OPS are shown in Table 1. The OPS was sieved using a $2.36 \mathrm{~mm}$ sieve to remove the fine particles of OPS. Mining sand was used as fine aggregate. The fineness modulus, specific gravity and water absorption of mining sand are $2.68,2.7$ and $1.0 \%$, respectively.

Table 1. Physical properties of OPS

\begin{tabular}{lc}
\hline Properties & Value \\
\hline Maximum size, $\mathrm{mm}$ & 16.5 \\
\hline Fineness modulus & 6.41 \\
\hline Bulk Density (loose condition), $\mathrm{kg} / \mathrm{m}^{3}$ & 538 \\
\hline Bulk Density (compacted condition), $\mathrm{kg} / \mathrm{m}^{3}$ & 635 \\
\hline Water absorption (1 hr), \% & 16.4 \\
\hline Water absorption (24 hrs), \% & 24.3 \\
\hline Specific gravity (oven-dry) & 1.08 \\
\hline Specific gravity (SSD) & 1.37 \\
\hline Apparent specific gravity & 1.46 \\
\hline Aggregate impact value (AIV), \% & 2.11 \\
\hline LA abrasion value, \% & 5 \\
\hline Flakiness index, FI, \% & 41 \\
\hline Elongation index, EI, \% & 59 \\
\hline
\end{tabular}




\subsubsection{Water and superplastcizer}

Potable water with a $\mathrm{pH}$ value of 6.20 was used for all mixes. A polycarboxylate-based superplasticizer was used in all mixes.

\subsubsection{Steel fibres}

Hooked end steel fibres of three different aspect ratios (1/d) were added into OPSC; the three different $1 / \mathrm{d}$ were 55,65 and 80 denoted as S1, S2 and S3, respectively. The physical appearances and geometries of all three fibres are shown in Figure 1 and Table 2, respectively.

\subsubsection{Mix proportions}

A total of ten OPSC mixes, as shown in Table 3, were prepared. One of the mixes is the control concrete without steel fibres. The variables investigated in this research are aspect ratio $(1 / d)$ and volume fraction $\left(V_{f}\right)$ of the steel fibres. For each $1 / \mathrm{d}$, three different mixes with $\mathrm{V}_{\mathrm{f}}$ of $0.25 \%, 0.50 \%$ and $0.75 \%$ of concrete volume were prepared and investigated. The cement content, water to cement $(\mathrm{w} / \mathrm{c})$ ratio and the quantity of, superplasticizer were kept constant at $530 \mathrm{~kg} / \mathrm{m}^{3}, 0.30$, and $0.65 \%$ of cement weight, respectively for all mixes. Further, the sand
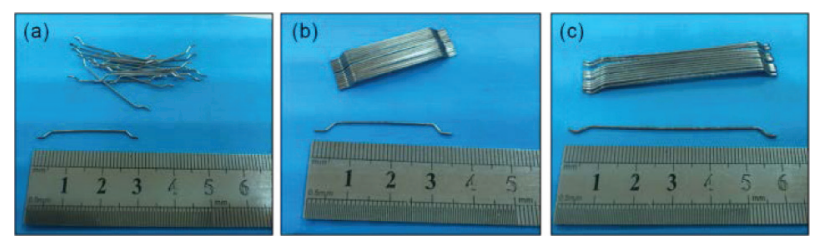

Fig. 1. Hooked end steel fibres: a) S1; b) S2; and c) S3

Table 2. Geometries of steel fibres

\begin{tabular}{|c|c|c|c|c|c|}
\hline $\begin{array}{l}\text { Steel } \\
\text { fibre }\end{array}$ & $\begin{array}{c}\text { Specific } \\
\text { gravity }\end{array}$ & $\begin{array}{l}\text { Length } \\
(\mathrm{mm})\end{array}$ & $\begin{array}{l}\text { Diameter } \\
(\mathrm{mm})\end{array}$ & $\begin{array}{l}\text { Aspect } \\
\text { ratio }(1 / d)\end{array}$ & Geometry \\
\hline S1 & \multirow{3}{*}{7.9} & 30 & 0.55 & 55 & \multirow{3}{*}{$\begin{array}{c}\text { Hooked } \\
\text { end }\end{array}$} \\
\hline S2 & & 35 & 0.55 & 65 & \\
\hline S3 & & 60 & 0.75 & 80 & \\
\hline
\end{tabular}

Table 3. Mix proportions

\begin{tabular}{ccccc}
\hline \multirow{2}{*}{ No. } & \multirow{2}{*}{ Mix } & \multicolumn{3}{c}{ Fibre (\% vol.) } \\
\cline { 3 - 5 } & & S1 & S2 & S3 \\
\hline 1 & Control & 0 & 0 & 0 \\
\hline 2 & S1/25 & 0.25 & 0 & 0 \\
\hline 3 & S1/50 & 0.50 & 0 & 0 \\
\hline 4 & $\mathrm{~S} 1 / 75$ & 0.75 & 0 & 0 \\
\hline 5 & $\mathrm{~S} 2 / 25$ & 0 & 0.25 & 0 \\
\hline 6 & $\mathrm{~S} 2 / 50$ & 0 & 0.50 & 0 \\
\hline 7 & $\mathrm{~S} 2 / 75$ & 0 & 0.75 & 0 \\
\hline 8 & $\mathrm{~S} 3 / 25$ & 0 & 0 & 0.25 \\
\hline 9 & $\mathrm{~S} 3 / 50$ & 0 & 0 & 0.50 \\
\hline 10 & $\mathrm{~S} 3 / 75$ & 0 & 0 & 0.75 \\
\hline
\end{tabular}

and OPS contents used in all mixes were $970 \mathrm{~kg} / \mathrm{m}^{3}$ and $320 \mathrm{~kg} / \mathrm{m}^{3}$, respectively.

\subsection{Mixing, specimen preparation and testing}

First, the OPS was soaked in water for 24 hours and then it was left in the air-dry condition for another 24 hours in order to ensure a saturated surface-dry (SSD) condition. The OPS was used in the SSD condition to prevent the water added in the mix from being absorbed by the OPS. First, the sand and OPS were mixed. This was followed by the addition of cement and SF. After thorough mixing, the water and superplasticizer were added. Finally, the fibres were dispersed into the mixer. The slump test, in accordance with ASTM C143 (2010), was used to measure the workability of OPSFRC. The fresh density of OPSFRC was also measured.

The following specimens were prepared for hardened concrete property tests: cubes of $100 \mathrm{~mm}$ were used for the compressive strength and UPV of concrete at ages of 1-, 3-, 7-, 28- and 56-day based on BS EN 12390-2 (2000) and BS EN 12390-3 (2000) and ASTM C597 (1997). After the compressive strength test, the cubes were reloaded to obtain the post-failure compressive strength (PFCS). The specimens of $100 \mathrm{~mm}$ diameter $\times 200 \mathrm{~mm}$ height cylinders, $100 \times 100 \times 500 \mathrm{~mm}$ prisms, $150 \mathrm{~mm}$ diameter $\times$ $300 \mathrm{~mm}$ height cylinders were used for the splitting tensile strength (ASTM C496 2004), flexural strength (ASTM C78 2002) and modulus of elasticity (ASTM C469 1997), respectively at the age of 28-day.

\section{Results and discussion}

\subsection{Workability}

The slump values for fresh concrete are shown in Table 4. The addition of steel fibres in the OPSC resulted in a decrease in the workability. The ranges of slump were $55-70 \mathrm{~mm}$, 50-60 $\mathrm{mm}$ and $20-45 \mathrm{~mm}$ for volume fraction $\left(\mathrm{V}_{\mathrm{f}}\right)$ of $0.25 \%, 0.50 \%$ and $0.75 \%$ steel fibres, respectively. The corresponding reductions in the workability were $7-27 \%$, $20-33 \%$ and $40-73 \%$ compared to the control concrete.

The concrete with steel fibres of aspect ratio of 55 (S1) produced the lowest slump compared with concrete with steel fibres of other aspect ratios: 65 (S2) and 80 (S3) for all volume fractions. With $\mathrm{V}_{\mathrm{f}}=0.25 \%$, the highest slump was achieved for S3/25 mix. One of the observations on the effect of the aspect ratio on the workability of OPSFRC is the effectiveness of the dispersion of the steel fibres in the mix. From Figure 2, the effective zone is denoted by the matrix region surrounding the fibre, which provides an additional tensile strength due to the fibre-matrix bond. The S2 mix showed the best dispersion among the mixes in which the overlapping of the effective zone of steel fibres is minimal for the same volume fraction of steel fibres, as illustrated in Figure 2. The steel fibre, S2 is approximately twice as long than the maximum size of OPS aggregate, thus it is effective in binding both the coarse and fine aggregate in that vicinity (Fig. 2(b)). Although S3 with a fibre length 
Table 4. Fresh and mechanical properties of OPSC

\begin{tabular}{|c|c|c|c|c|c|c|c|c|c|}
\hline \multirow{3}{*}{ Mix } & \multirow{3}{*}{$\begin{array}{l}\text { Slump } \\
(\mathrm{mm})\end{array}$} & \multicolumn{8}{|c|}{ Mechanical properties } \\
\hline & & \multicolumn{5}{|c|}{ Compressive strength (MPa) } & \multirow{2}{*}{$\begin{array}{c}\text { 28-day splitting } \\
\text { tensile strength (MPa) }\end{array}$} & \multirow{2}{*}{$\begin{array}{l}\text { 28-day flexural } \\
\text { strength }(\mathrm{MPa})\end{array}$} & \multirow{2}{*}{$\begin{array}{l}\text { 28-day modulus } \\
\text { of elasticity (GPa) }\end{array}$} \\
\hline & & 1-day & 3-day & 7-day & $\begin{array}{l}28- \\
\text { day }\end{array}$ & 56-day & & & \\
\hline Control & 75 & 19.1 & 25.8 & 32.7 & 34.8 & 35.3 & 3.22 & 4.90 & 13.25 \\
\hline $\mathrm{S} 1 / 25$ & 55 & 26.4 & 34.8 & 37.6 & 39.5 & 42.2 & 4.11 & 5.13 & 16.30 \\
\hline $\mathrm{S} 1 / 50$ & 50 & 21.2 & 26.3 & 29.0 & 38.7 & 38.7 & 3.77 & 5.23 & 16.03 \\
\hline $\mathrm{S} 1 / 75$ & 20 & 21.6 & 27.4 & 32.1 & 40.2 & 40.5 & 4.13 & 5.38 & 15.57 \\
\hline $\mathrm{S} 2 / 25$ & 65 & 21.3 & 30.4 & 40.7 & 43.7 & 43.8 & 4.40 & 5.58 & 16.21 \\
\hline $\mathrm{S} 2 / 50$ & 60 & 23.1 & 31.7 & 35.0 & 45.2 & 45.5 & 4.78 & 5.87 & 15.80 \\
\hline $\mathrm{S} 2 / 75$ & 45 & 22.7 & 33.6 & 39.0 & 46.6 & 46.6 & 5.90 & 6.56 & 14.15 \\
\hline $\mathrm{S} 3 / 25$ & 70 & 20.0 & 26.6 & 33.0 & 37.3 & 40.6 & 4.07 & 5.53 & 14.64 \\
\hline $\mathrm{S} 3 / 50$ & 60 & 22.5 & 27.9 & 32.0 & 41.5 & 42.7 & 4.70 & 5.69 & 14.22 \\
\hline $\mathrm{S} 3 / 75$ & 35 & 21.5 & 26.4 & 33.5 & 39.7 & 40.2 & 5.71 & 7.00 & 13.58 \\
\hline
\end{tabular}

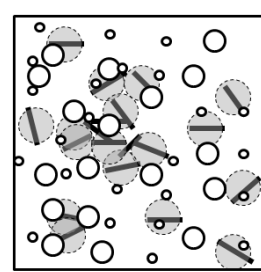

(a)

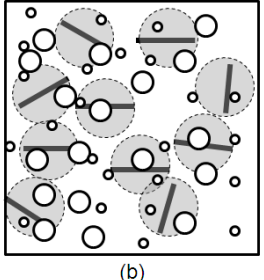

(b)

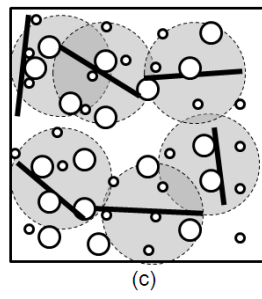

Effectivezone

Fig. 2. Graphical illustrations of dispersion of steel fibres: a) $\mathrm{S} 1$; b) $\mathrm{S} 2$; and c) $\mathrm{S} 3$

of $60 \mathrm{~mm}$ was effective to bind more aggregate, due to its long geometry, the dispersion of fibres was not uniform (Fig. 2(c)). The small-sized fibre, S1 has more fibres for a given volume compared to S2 and S3. Hence, they have a higher possibility of clogging together, and, eventually, increasing the overlapping of the effective zone, as shown in Figure 2(a). The clogging of fibres reduced the workability of OPSFRC and the mix S1 produced the lowest workability. Thus, it can be concluded that steel fibre with a moderate aspect ratio is preferred for workable OPSFRC.

The effect of $\mathrm{V}_{\mathrm{f}}$ in the concrete was evident when the $\mathrm{V}_{\mathrm{f}}$ was increased from $0.25 \%$ to $0.75 \%$. In the concrete specimens with $0.75 \%$ of fibres, the clogging of the hooked end fibres was visible in certain sections. In the S1/75 mix, the workability achieved was very poor, which might be attributed to both the quantity and length of fibre. As stated earlier in this section, the quantity of fibre in the S1 category was higher compared to the others, which, combined with a high volume fraction of fibres, contributed to the poor workability.

\subsection{Density}

Density is the most important criteria in the classification of the LWAC. The following discussions are focused on the effects of steel fibres and drying conditions on the fresh and hardened densities of OPSFRC.

\subsubsection{Fresh density}

Table 5 shows the values of fresh densities of the control concrete and OPSFRC with steel fibres of three different $1 / \mathrm{d}$ and $\mathrm{V}_{\mathrm{f}}$. It can be seen that the fresh concrete density increased by about $5-190 \mathrm{~kg} / \mathrm{m}^{3}(0.3-10 \%)$ with the addition of steel fibres.

The effect of the aspect ratio and the volume fraction of steel fibres on the fresh density of OPSFRC is shown in Figure 3. In general, the steel fibres with higher $1 / \mathrm{d}$ resulted in a higher increment of fresh density. The $\mathrm{S} 2$ and S3 mixes showed a higher fresh density of about $60-150 \mathrm{~kg} / \mathrm{m}^{3}(3-8 \%)$ and $90-190 \mathrm{~kg} / \mathrm{m}^{3}(5-10 \%)$, respectively, than the control concrete. However, the increase of density of the S1 mix was insignificant $(<1 \%)$ compared to the control concrete. Further, the S2 and S3 mixes produced about $55-170 \mathrm{~kg} / \mathrm{m}^{3}$ higher density than the S1 mix. As discussed in Section 2.1, the use of steel fibres with low $1 / \mathrm{d}$ results in clogging of fibres that caused poor workability. Thus, the ability of mortar to flow into the void is restricted and the $\mathrm{S} 1$ mix produced a lower density compared to S2 and S3.

The effect of the $\mathrm{V}_{\mathrm{f}}$ of steel fibre on the fresh density of OPSFRC is seen in Figure 3. The specific gravity of

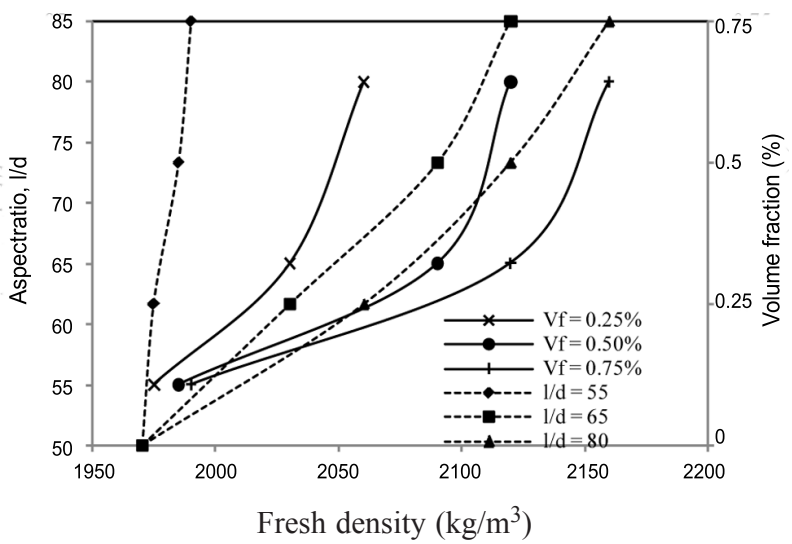

Fig. 3. Influence of aspect ratio (1/d) and volume fraction on fresh density 
steel fibre is 7.9 , which is relatively higher compared to the other constituent materials in the OPSC. Hence, the large quantity of steel fibres added in OPSC increases the fresh density. When the $\mathrm{V}_{\mathrm{f}}$ of the fibres increased from $0.25 \%$ to $0.75 \%$, the corresponding increase in the fresh density was found to be about $0.5 \%, 4.5 \%$ and $5.0 \%$ for mixes $\mathrm{S} 1, \mathrm{~S} 2$ and $\mathrm{S} 3$, respectively.

\subsubsection{Hardened density}

The hardened concrete densities of the mixes are shown in Table 5. The hardened densities include saturated surface dry (SSD), air-dry and oven-dry densities and the average density measured at the age of 28-day. This section aims to compare the effect of air-drying and oven-drying on the hardened densities of OPSFRC. Concrete with an oven-dry density of not greater than $2000 \mathrm{~kg} / \mathrm{m}^{3}$ can be defined as structural LWC (Newman, Owens 2003). All the mixes except $\mathrm{S} 2 / 50$ and $\mathrm{S} 2 / 75$ produced an oven-dry density of less than $2000 \mathrm{~kg} / \mathrm{m}^{3}$, and, hence, the concrete could be considered as structural LWC.

The effect of $1 / d$ and $V_{f}$ on the hardened concrete densities is similar to that of the fresh density. It was observed that the reduction of oven-dry density of control concrete was $12 \%$ compared to its SSD and the highest among the mixes. The OPSFRC produced a density reduction of about $0.5-2 \%$ and $6-8 \%$ in airdry and oven-dry conditions, respectively. The addition of fibres contributed to the reduction in the air-dry and oven-dry densities compared to the control concrete. This could be attributed to the higher OPS content in the control concrete compared to OPSFRC as OPS has a 24-hour water absorption of about $24 \%$.

\subsection{Hardened concrete properties}

\subsubsection{Compressive strength}

The compressive strengths of all mixes are shown in Table 4. All the mixes produced a high early compressive strength of $48-55 \%, 67-88 \%$ and $77-95 \%$ of the 28 -day strength at the ages of 1-, 3- and 7-day, respectively. The addition of SF

Table 5. Fresh and hardened densities of OPSC

\begin{tabular}{lcccc}
\hline Mix & $\begin{array}{c}\text { Fresh } \\
\text { density } \\
\left(\mathrm{kg} / \mathrm{m}^{3}\right)\end{array}$ & $\begin{array}{c}\text { SSD } \\
\text { density } \\
\left(\mathrm{kg} / \mathrm{m}^{3}\right)\end{array}$ & $\begin{array}{c}\text { Air-dry } \\
\text { density } \\
\left(\mathrm{kg} / \mathrm{m}^{3}\right)\end{array}$ & $\begin{array}{c}\text { Oven-dry } \\
\text { density } \\
\left(\mathrm{kg} / \mathrm{m}^{3}\right)\end{array}$ \\
\hline Control & 1970 & 2050 & 1950 & 1800 \\
\hline $\mathrm{S} 1 / 25$ & 1975 & 1990 & 1970 & 1840 \\
\hline $\mathrm{S} 1 / 50$ & 1985 & 1990 & 1970 & 1830 \\
\hline $\mathrm{S} 1 / 75$ & 1990 & 2000 & 1980 & 1850 \\
\hline $\mathrm{S} 2 / 25$ & 2030 & 2120 & 2110 & 1980 \\
\hline $\mathrm{S} 2 / 50$ & 2090 & 2140 & 2130 & 2010 \\
\hline $\mathrm{S} 2 / 75$ & 2120 & 2150 & 2140 & 2030 \\
\hline $\mathrm{S} 3 / 25$ & 2060 & 2130 & 2110 & 1980 \\
\hline $\mathrm{S} 3 / 50$ & 2120 & 2110 & 2100 & 1970 \\
\hline $\mathrm{S} 3 / 75$ & 2160 & 2170 & 2130 & 1990 \\
\hline
\end{tabular}

and its effect on the early strength in this research is quite similar to the reported results of Alengaram et al. (2010b). The pozzolanic and micro-filling effects of SF enhance the aggregate-paste bond and the compressive strength of OPSC at an early age (Teo et al. 2007; Nili, Afroughsabet 2010). The addition of SF also results in an increase of cohesiveness of the matrix that normally minimizes the induction of micro-cracks, and, consequently, increases the early strength (Nili, Afroughsabet 2012). From Table 4, the 56-day compressive strength of all mixes show a slight increase of $0-7 \%$ compared to the 28 -day strength. The strength development was found to be independent of the aspect ratio and volume fraction of steel fibres.

The 28-day compressive strengths of the mixes fall in the range of 35-47 MPa, as shown in Table 4 and Figure 4. As expected, the addition of steel fibres enhanced the compressive strength of OPSC by $7-33 \%$. As seen from Figure 4, the mix S2/75 produced the highest 28-day compressive strength of about $47 \mathrm{MPa}$.

The effect of fibres on the compressive strength was evident, as the comparison of strength of the mixes $\mathrm{S} 1$, $\mathrm{S} 2$ and $\mathrm{S} 3$ shows a respective increment of $14 \%, 33 \%$ and $16 \%$ for $\mathrm{V}_{\mathrm{f}}=0.75 \%$, compared with the control concrete. S2 has $16 \%$ and $18 \%$ higher strength than that of $\mathrm{S} 1$ and S3. The overall comparison of the S2 mix with the control showed an increment in compressive strength of $26 \%, 30 \%$ and $33 \%$ for $\mathrm{V}_{\mathrm{f}}$ of $0.25 \%, 0.50 \%$ and $0.75 \%$, respectively. A similar comparison for $\mathrm{S} 1$ and $\mathrm{S} 3$ showed $14 \%, 11 \%$ and $16 \%$ and $7 \%, 19 \%$ and $14 \%$ for volume fraction $\mathrm{V}_{\mathrm{f}}$ of $0.25 \%, 0.5 \%$ and $0.75 \%$, respectively. The incorporation of steel fibre into the matrix increased the ultimate compressive strength by arresting the growth of cracks due to the bond between the steel fibre and the cement matrix (Gao et al. 1997). The addition of steel fibres beyond $0.25 \%$ resulted in less crack formation and higher compressive strength.

The effect of $V_{f}$ on the 28-day compressive strength was not significant when it was increased from $0.50 \%$ to $0.75 \%$; a drop in $\mathrm{S} 3$ and a slight increase in $\mathrm{S} 1$ and $\mathrm{S} 2$ was evident. This might be attributed to the high aspect ratio of the steel fibres, as the dispersion of fibres

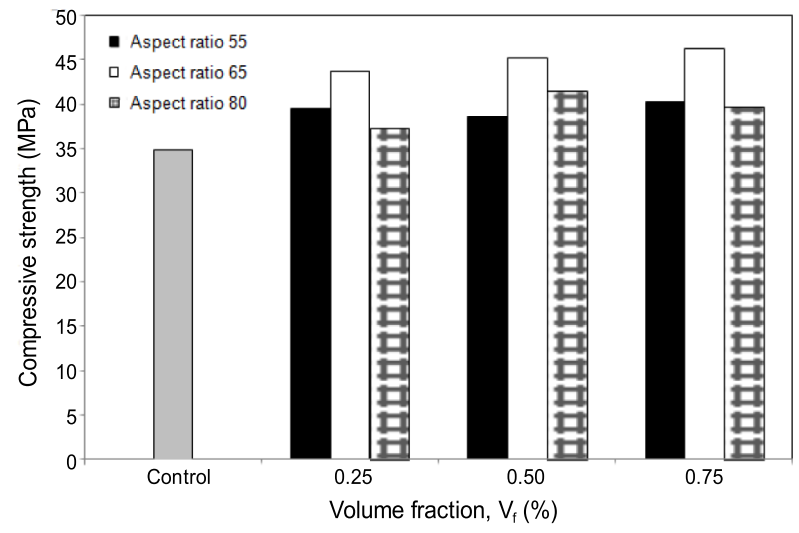

Fig. 4. Effect of volume fraction and aspect ratio on compressive strength 
becomes more difficult. Thus, the effect of the increase in $\mathrm{V}_{\mathrm{f}}$ on the compressive strength beyond $0.50 \%$ becomes insignificant or rather inconsistent. The results are in agreement with the published works of Gao et al. (1997) and Libre et al. (2011).

\subsubsection{Splitting tensile strength}

The splitting tensile strength is an important design parameter for beams and it provides an indication of the shear strength of concrete in diagonal tension (Düzgün et al. 2005). Compared to NWC, LWAC produces a lower splitting tensile strength. The addition of steel fibres enhances the splitting tensile strength of structural LWAC (Düzgün et al. 2005; Shafigh et al. 2011).

The splitting tensile strengths of all mixes are shown in Table 4. The highest value of $5.90 \mathrm{MPa}$ was obtained for $\mathrm{S} 2 / 75$. The increase in splitting tensile strength of OPSFRC is in the range of $17-83 \%$, which, compared to OPSC, showed that the effect of steel fibres was significant on the splitting tensile strength. The ratio of 28-day splitting tensile strength to its corresponding compressive strength showed $10-14 \%$, which could be compared to the $8-10 \%$ for NWC. This ratio increased with the increase in $V_{f}$.

The average increment of the splitting tensile strength for all aspect ratios for OPSFRC with a $\mathrm{V}_{\mathrm{f}}$ of $0.25 \%, 0.50 \%$ and $0.75 \%$ were $30 \%, 37 \%$ and $62 \%$, respectively, compared to the control concrete. The highest increase in the splitting tensile strength was observed for $\mathrm{S} 2$ and $\mathrm{S} 3$ mixes with $\mathrm{V}_{\mathrm{f}}=0.75 \%$. For specimens with $\mathrm{V}_{\mathrm{f}}$ less than $0.50 \%$, the increase was insignificant.

The effect of $1 / d$ on the splitting tensile strength was obvious in OPSFRC. The highest tensile strength was obtained for S2 and S3 mixes, while the S1 mix produced a lower strength compared to these two mixes. At $\mathrm{V}_{\mathrm{f}}=0.75 \%$ where the highest splitting tensile strength was observed, S1 produced $43 \%$ and $38 \%$ lower splitting tensile strength than S2 and S3, respectively.

The visual observation on the specimens tested showed different crack patterns for the control and OPSFRC (Fig. 5). The cracks in the control specimens were wider compared to the shorter and narrower cracks in the OPSFRC. Further, the OPSFRC with $\mathrm{V}_{\mathrm{f}}=0.25 \%$ showed a different crack pattern compared to the other two $\mathrm{V}_{\mathrm{f}}$; the cracks in the OPSFRC with $\mathrm{V}_{\mathrm{f}}$ of $0.50 \%$ and $0.75 \%$ exhibit much narrower and shorter cracks compared to $V_{f}$ with $0.25 \%$. Thus, it is evident that a fibre content higher than $0.25 \%$ improved the splitting tensile strength and reduced the crack width and length. A similar observation was reported by Gao et al. (1997).

The equation developed by Gao et al. (1997) to correlate the splitting tensile strength to $\mathrm{V}_{\mathrm{f}}$ and $\mathrm{l} / \mathrm{d}$ of LWAC is shown in Eqn (1). This equation applies to steel fibres with a length of $30 \mathrm{~mm}$ and below. Eqn (1) could be used to predict the splitting tensile strength of the mix $\mathrm{S} 1$ within $\pm 0.6 \mathrm{MPa}$. However, a slight modification to equation 1 was done to predict the strength for fibre lengths of more than $30 \mathrm{~mm}$, as shown in Eqn (2). This equation predicted the splitting tensile strength of mixes $\mathrm{S} 2$ and $\mathrm{S} 3$ within $\pm 0.5 \mathrm{MPa}$ :

$$
\begin{aligned}
& \mathrm{f}_{\mathrm{st}}=0.94 \mathrm{f}_{\mathrm{t}}\left(1-\mathrm{V}_{\mathrm{f}}\right)+3.02 \mathrm{~V}_{\mathrm{f}}(1 / \mathrm{d}) ; \\
& \mathrm{f}_{\mathrm{st}}=1.18 \mathrm{f}_{\mathrm{t}}\left(1-\mathrm{V}_{\mathrm{f}}\right)+3.04 \mathrm{~V}_{\mathrm{f}}(1 / \mathrm{d}),
\end{aligned}
$$

where: $f_{t}$ - splitting tensile strength of LWAC (MPa); $\mathrm{f}_{\text {st }}$ - splitting tensile strength of steel fibre-reinforced LWAC (MPa).

\subsubsection{Flexural strength}

Table 4 shows the flexural strength of all mixes, which ranged from 4.90-7.00 MPa. The flexural strength is a significant parameter and similar to the splitting tensile strength, it increases with the addition of steel fibres. The mechanism for the increase in the flexural strength is attributed to the strong fibre-matrix bond (Gao et al. 1997; Shafigh et al. 2011).

The flexural strength to the compressive strength ratio was $15 \%$ for the control concrete. However, this ratio was $14 \%$ for OPSFRC; the slight decrease could be attributed to the higher compressive strength of OPSFRC.

The OPSC specimens depicted typical flexural failure for specimens under two-point loading. However, the OPSFRC specimens with steel fibres showed ductile failure with progressive debonding of fibres. The final failure of OPSFRC happened due to unstable crack propagation when the fibres pulled out and the interfacial shear stress reached the ultimate bond strength (Gao et al. 1997).

Figure 6 shows the effect of $1 / d$ on crack formation when OPSFRC failed under flexural. The effect of $1 / d$ on the crack formation and its width was obvious; as the aspect ratio increased, a shorter and narrower crack width was found to form in all OPSFRC specimens. The highest flexural strength of 7.00 MPa obtained for the

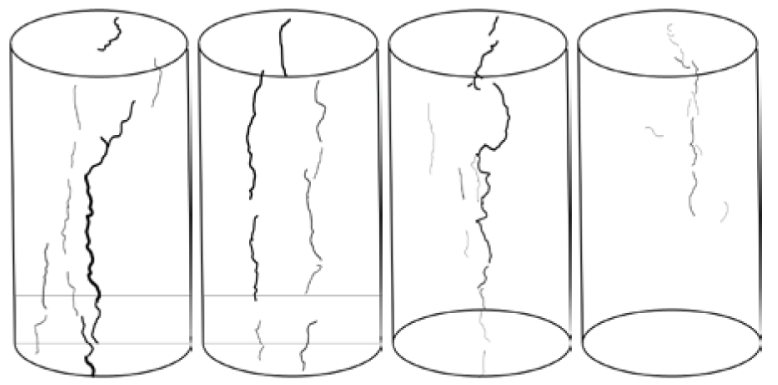

Fig. 5. Sketches of crack patterns: a) control; b) S3/25; c) $\mathrm{S} 3 / 50$; and d) $\mathrm{S} 3 / 75$

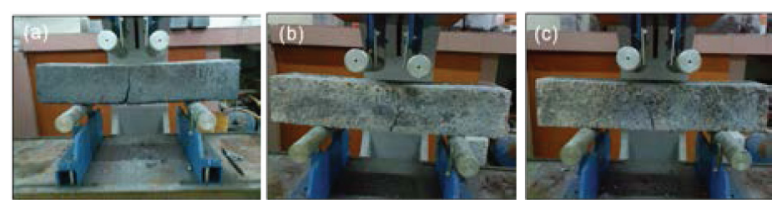

Fig. 6. Flexural failure of S1/50 (a); S2/50 (b); and S3/50 (c) 


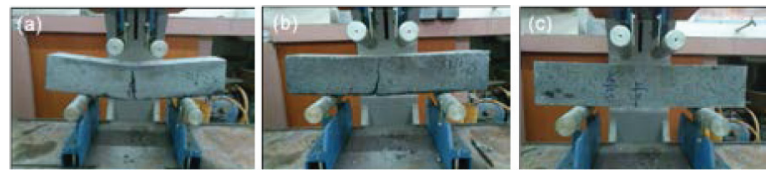

Fig. 7. Flexural failure of $\mathrm{S} 1 / 25$ (a); S1/50 (b); and S1/75 (c)

S3/75 mix with the $1 / d=80$ could be attributed to the large anchorage length of the fibres. The S1 mix with $1 / \mathrm{d}=55$ produced lower flexural strength compared to other mixes. The effect of $V_{f}$ on the cracks is similar to that reasoned for aspect ratio (Fig. 7). The increase in $\mathrm{V}_{\mathrm{f}}$ from $0.25 \%$ to $0.75 \%$ produced stronger bond between the matrix and the fibres that enhanced the flexural strength.

Similar to the equation proposed for the splitting tensile strength, Eqn (3), as suggested by Gao et al. (1997), was modified to suit the OPSFRC. This is shown in equation 4 and could be used to predict the flexural strength of OPSFRC within $\pm 0.5 \mathrm{MPa}$ with fibres of $1 / \mathrm{d}$ and $\mathrm{V}_{\mathrm{f}}$ of ranges $55-80$ and $0.25-0.75 \%$, respectively:

$$
\begin{aligned}
& \mathrm{f}_{\mathrm{sw}}=0.92 \mathrm{f}_{\mathrm{w}}\left(1-\mathrm{V}_{\mathrm{f}}\right)+4.19 \mathrm{~V}_{\mathrm{f}}(1 / \mathrm{d}) ; \\
& \mathrm{f}_{\mathrm{sw}}=0.86 \mathrm{f}_{\mathrm{w}}\left(1-\mathrm{V}_{\mathrm{f}}\right)+3.20 \mathrm{~V}_{\mathrm{f}}(1 / \mathrm{d}),
\end{aligned}
$$

where: $\mathrm{f}_{\mathrm{w}}$ - flexural strength of LWAC (MPa); $\mathrm{f}_{\mathrm{sw}}-$ flexural strength of steel fibre-reinforced LWAC (MPa).

\subsubsection{Modulus of elasticity}

Table 4 shows the values of the modulus of elasticity (MOE) for all mixes. As expected, the addition of steel fibres improved the MOE of OPSFRC. The S1 mix produced the highest MOE in the range of $15.57-16.30 \mathrm{GPa}$, which showed an increment of $18-23 \%$ compared to the control concrete. A similar comparison for the S2 and S3 mixes showed an increment of $7-22 \%$ and $3-11 \%$, respectively.

The MOE obtained at $\mathrm{V}_{\mathrm{f}}=0.25 \%$ was the highest compared to other $\mathrm{V}_{\mathrm{f}}$ for all aspect ratios. The highest MOE was obtained for the S1 mix with $16.30 \mathrm{GPa}$, which is $1 \%$ and $11 \%$ higher than the $\mathrm{S} 2$ and $\mathrm{S} 3$ mixes, respectively. The effect of $1 / d$ and $V_{f}$ on the MOE was observed for all mixes; the higher the $1 / d$ and $V_{f}$ values, the lower the MOE. OPS is of organic origin, and hence, it has a lower stiffness and restraining effect compared to crushed granite aggregate. Thus, when the load is applied, the OPS undergoes a higher strain, which resulted in a lower MOE in the OPSC compared to the NWC (Alengaram et al. 2011a). Similar to the discussion in Section 2.3.1, the addition of SF and fibre-matrix bond enhanced the strength and a higher MOE was obtained for OPSFRC compared to OPSC.

\subsection{Ultrasonic pulse velocity (UPV)}

The ultrasonic pulse velocity (UPV) values for all mixes are shown in Table 6. UPV test is a non-destructive
Table 6. Ultrasonic pulse velocity (UPV) of OPSC

\begin{tabular}{lccccc}
\hline \multirow{2}{*}{ Mix } & \multicolumn{5}{c}{ UPV at different ages $(\mathrm{km} / \mathrm{s})$} \\
\cline { 2 - 6 } & 1-day & 3-day & 7-day & 28-day & 56-day \\
\hline Control & 3.39 & 3.52 & 3.70 & 4.08 & 4.10 \\
\hline $\mathrm{S} 1 / 25$ & 3.47 & 3.94 & 3.96 & 4.11 & 4.13 \\
\hline $\mathrm{S} 1 / 50$ & 3.36 & 3.70 & 3.80 & 4.01 & 4.10 \\
\hline $\mathrm{S} 1 / 75$ & 3.36 & 3.73 & 3.98 & 4.09 & 4.12 \\
\hline $\mathrm{S} 2 / 25$ & 3.37 & 3.79 & 3.83 & 4.18 & 4.22 \\
\hline $\mathrm{S} 2 / 50$ & 3.20 & 3.76 & 3.92 & 3.99 & 4.18 \\
\hline $\mathrm{S} 2 / 75$ & 3.36 & 3.87 & 3.94 & 4.08 & 4.11 \\
\hline $\mathrm{S} 3 / 25$ & 3.41 & 3.73 & 3.97 & 4.01 & 4.04 \\
\hline $\mathrm{S} 3 / 50$ & 3.39 & 3.79 & 3.83 & 3.93 & 4.12 \\
\hline $\mathrm{S} 3 / 75$ & 3.39 & 3.67 & 3.82 & 3.88 & 4.05 \\
\hline
\end{tabular}

test (NDT) and used to assess the uniformity and relative quality of concrete, to indicate the presence of voids and cracks, and to estimate the depth of cracks (ASTM C597 1997). As seen from Table 6, the UPV values of all OPSFRC are quite close to the UPV values of control concrete at all ages. The results from Table 6 indicate that the addition of steel fibres into OPSFRC did not influence the UPV values.

According to Leslie and Cheeseman (1949), concrete with a UPV within the range of $3.66-4.57 \mathrm{~km} / \mathrm{s}$ is considered of good quality and concrete with a UPV of more than $4.57 \mathrm{~km} / \mathrm{s}$ is of excellent quality. Concrete with excellent quality possesses uniformity and negligible internal voids or cracks while concrete of good quality attains good uniformity due to proper compaction and minimal internal voids or cracks occur. The UPV values at the age of 3-day showed that all the mixes attained the minimum required value of $3.66 \mathrm{~km} / \mathrm{s}$ specified for good quality concrete. The results supplemented the observation mentioned in the discussion in Section 2.3.1 on high early compressive strength for all mixes. In addition, the trend of UPV values showed that there is an increase of $10 \%$ at the age of 56-day compared to the 3-day average values.

An empirical equation based on regression analysis from Figure 8 is proposed to evaluate the compressive strength $\left(f_{c u}\right)$ based on the UPV values for OPSFRC:

$$
\mathrm{f}_{\mathrm{cu}}=0.43(\mathrm{v})^{3.2}
$$

where: $f_{c u}-$ Compressive strength (MPa); v - UPV value $(\mathrm{km} / \mathrm{s})$.

\subsection{Post-failure compressive strength}

The post-failure compressive strength (PFCS) is an important factor that was investigated in this work using cube specimens. The cube specimens that were tested and failed in the compressive strength test were reloaded to ascertain their PFCS. The PFCS is an indication of the post-failure compressive toughness of the concrete. 


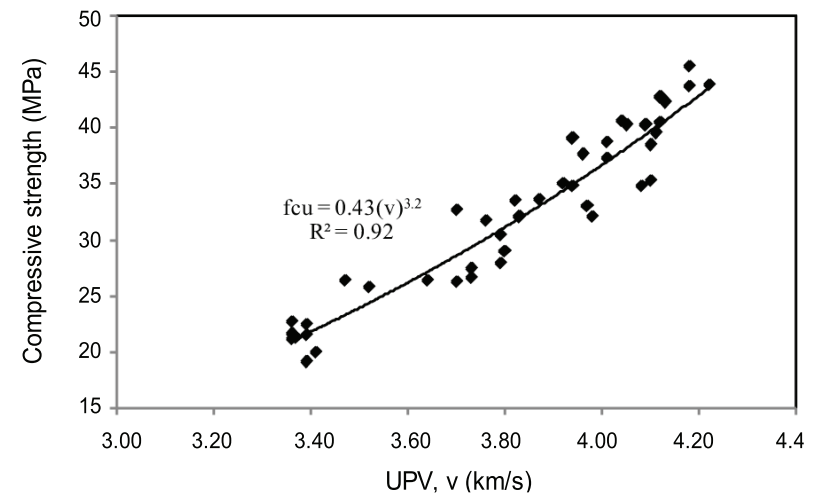

Fig. 8. Relationship between compressive strength and UPV values

Studies (Nataraja et al. 2000) have shown that steel fibres increased the toughness of concrete; however, no literature is available to verify the toughness of concrete by reloading the specimen tested for compression.

The PFCS values are shown in Table 7. The average values of the percentage of the PFCS with their respective compressive strength at the ages of 1-, 3-, 7-, 28- and 56-day are shown in the last column. From the results, it can be seen that the addition of steel fibres enhanced the PFCS by $1.8-6.4 \%$ compared to the control concrete. In general, the higher aspect ratio and $\mathrm{V}_{\mathrm{f}}$ increased PFCS. The increase in PFCS might be attributed to a strong fibre-matrix bond even after the failure of concrete. The fibre-matrix bond enabled the fibre to hold the concrete together and inhibit further crack initiation and propagation.

\section{Conclusions}

In this investigation the effect of $1 / d$ and $V_{f}$ on OPSFRC was studied. The fresh and hardened concrete properties were investigated. UPV were measured to correlate com- pressive strength of OPSFRC. Based on the study, the following conclusions were drawn:

- The slump for all mixes was in the range of 20-70 mm. It was observed that the increase in $\mathrm{V}_{\mathrm{f}}$, reduced the workability of OPSFRC irrespective of $1 / d$.

- The addition of fibres with high $1 / d$ and $V_{f}$ increased the fresh density in OPSFRC.

- The values of SSD density, air-dry density and oven-dry density of OPSFRC varied in the range of $1990-2170 \mathrm{~kg} / \mathrm{m}^{3}, 1970-2140 \mathrm{~kg} / \mathrm{m}^{3}$ and $1830-2030 \mathrm{~kg} / \mathrm{m}^{3}$, respectively.

- All mixes attained high early compressive strength, which is attributed to the pozzolanic and micro-filling effects of SF. Both effects increased the matrix cohesiveness and minimized the initiation of cracks.

- The mix S2 with 1/d of 65 produced the highest 28-day compressive strength of $47 \mathrm{MPa}$. The compressive strength of OPSFRC depends on the $1 / \mathrm{d}$, whilst higher fibre content has a positive effect on it.

- The steel fibres provided additional tensile strength due to the fibre-matrix bond that enhanced both the splitting tensile and flexural strengths of OPSFRC. A fibre content above $\mathrm{V}_{\mathrm{f}}$ of $0.50 \%$ produced a significant improvement in both the splitting tensile and the flexural strength.

- The lower stiffness of OPS can be overcome with the addition of fibres, and, hence, the MOE of OPSFRC was found to have increased $3-23 \%$ compared to the control concrete.

- The UPV results showed that they are independent of both $1 / \mathrm{d}$ and $\mathrm{V}_{\mathrm{f}}$ and all the OPSFRC mixes produced above $3.66 \mathrm{~km} / \mathrm{s}$ at the age of 3-day indicating good quality concrete.

- The post-failure compressive strength was used in this investigation to measure the post-failure compressive toughness. It showed that an increase in $1 / \mathrm{d}$ and $V_{f}$ had a positive impact.

Table 7. Post-failure compressive strength (PFCS) of OPSC and OPSFRC

\begin{tabular}{|c|c|c|c|c|c|c|c|c|c|c|c|}
\hline \multirow[b]{2}{*}{ Mix } & \multicolumn{2}{|c|}{ 1-day } & \multicolumn{2}{|c|}{ 3-day } & \multicolumn{2}{|c|}{ 7-day } & \multicolumn{2}{|c|}{ 28-day } & \multicolumn{2}{|c|}{ 56-day } & \multirow{2}{*}{$\begin{array}{l}\text { Average } \% \\
\text { of } \operatorname{CS}(\%)\end{array}$} \\
\hline & PFCS & $\begin{array}{c}\% \text { of } \\
\text { CS (\%) }\end{array}$ & PFCS & $\begin{array}{c}\% \text { of } \\
\text { CS (\%) }\end{array}$ & PFCS & $\begin{array}{c}\% \text { of CS } \\
(\%)\end{array}$ & PFCS & $\begin{array}{c}\% \text { of } \\
\text { CS (\%) }\end{array}$ & PFCS & $\begin{array}{c}\% \text { of } \\
\text { CS (\%) }\end{array}$ & \\
\hline Control & 12.5 & 63.8 & 16.7 & 64.7 & 20.7 & 63.3 & 22.2 & 63.8 & 22.5 & 63.7 & 63.9 \\
\hline $\mathrm{S} 1 / 25$ & 18.2 & 68.9 & 24.2 & 69.5 & 25.3 & 67.3 & 26.2 & 66.3 & 28.5 & 67.5 & 67.9 \\
\hline $\mathrm{S} 1 / 50$ & 14.9 & 70.3 & 17.4 & 66.1 & 19.5 & 67.2 & 23.5 & 60.7 & 24.8 & 64.7 & 65.8 \\
\hline $\mathrm{S} 1 / 75$ & 14.7 & 68.1 & 18.6 & 67.9 & 25.4 & 79.1 & 26.3 & 65.4 & 25.3 & 62.5 & 68.6 \\
\hline $\mathrm{S} 2 / 25$ & 13.0 & 61.0 & 20.8 & 68.4 & 26.8 & 65.8 & 29.5 & 67.5 & 28.8 & 65.8 & 65.7 \\
\hline $\mathrm{S} 2 / 50$ & 15.9 & 68.8 & 21.1 & 66.6 & 22.8 & 65.1 & 29.4 & 65.1 & 29.3 & 64.7 & 66.1 \\
\hline $\mathrm{S} 2 / 75$ & 15.4 & 67.8 & 23.2 & 69.0 & 26.7 & 68.5 & 32.0 & 68.5 & 33.0 & 71.4 & 69.0 \\
\hline $\mathrm{S} 3 / 25$ & 13.4 & 67.0 & 17.2 & 64.7 & 22.0 & 66.7 & 24.6 & 66.0 & 26.7 & 65.8 & 66.0 \\
\hline $\mathrm{S} 3 / 50$ & 15.6 & 69.3 & 18.4 & 65.9 & 21.0 & 65.6 & 29.0 & 69.9 & 32.3 & 75.6 & 69.2 \\
\hline $\mathrm{S} 3 / 75$ & 15.3 & 71.1 & 20.3 & 76.9 & 21.8 & 65.1 & 27.9 & 70.3 & 27.3 & 67.9 & 70.3 \\
\hline
\end{tabular}

Note: $\mathrm{PFCS}=$ post-failure compressive strength in $\mathrm{MPa} ; \mathrm{CS}=$ compressive strength. 


\section{Acknowledgements}

This research work was funded by the University of Malaya under the High Impact Research Grant (HIRG) No. UM.C/HIR/MOHE/ENG/02/D000002-16001 (synthesis of blast resistant structures). The authors are grateful to the Vice-Chancellor of University of Malaya for his noteworthy effort in securing funding through the above said project.

\section{References}

Alengaram, U. J.; Jumaat, M. Z.; Mahmud, H. 2008. Ductility behavior of reinforced palm kernel shell concrete beams, European Journal of Scientific Research 23(3): 406-420.

Alengaram, U. J.; Mahmud, H.; Jumaat, M. Z. 2010a. Comparison of mechanical and bond properties of oil palm kernel shell concrete with normal weight concrete, International Journal of Physical Science 5(8): 1231-1239.

Alengaram, U. J.; Jumaat, M. Z.; Mahmud, H.; Shirazi, S. M. $2010 \mathrm{~b}$. Effect of aggregate size and proportion on strength properties of palm kernel shell concrete, International Journal of Physical Science 5(12): 1848-1856.

Alengaram, U. J.; Mahmud, H.; Jumaat, M. Z. 2011a. Enhancement and prediction of modulus of elasticity of palm kernel shell concrete, Materials and Design 32(4): 2143 2148. http://dx.doi.org/10.1016/j.matdes.2010.11.035

Alengaram, U. J.; Jumaat, M. Z.; Mahmud, H.; Fayyadh, M. M. 2011b. Shear behaviour of reinforced palm kernel shell concrete beams, Construction and Building Materials 25(6): 2918-2927.

http://dx.doi.org/10.1016/j.conbuildmat.2010.12.032

Alengaram, U. J.; Al Muhit, B. A.; Jumaat, M. Z. 2013. Utilization of oil palm kernel shell as lightweight aggregate in concrete - a review, Construction and Building Materials 38: 161-172.

http://dx.doi.org/10.1016/j.conbuildmat.2012.08.026

Atiş, C. D.; Karahan, O. 2009. Properties of steel fiber reinforced fly ash concrete, Construction and Building Materials 23(1): 392-399.

http://dx.doi.org/10.1016/j.conbuildmat.2007.11.002

ASTM C143 Standard Test Method for Slump of Hydraulic Cement Concrete. American Society for Testing and Materials (ASTM), 2010.

ASTM C597 Standard test method for pulse velocity through concrete. American Society for Testing and Materials (ASTM), 1997.

ASTM C78 Standard test method for flexural strength of concrete (using simple beam with third-point loading). American Society for Testing and Materials (ASTM), 2002.

ASTM C469 Standard test method for static modulus of elasticity and Poisson's ratio of concrete in compression. American Society for Testing and Materials (ASTM), 1997.

ASTM C496 Standard test method for splitting tensile strength of cylindrical concrete specimens. American Society for Testing and Materials (ASTM), 2004.

Basri, H. B.; Mannan, M. A.; Zain, M. F. M. 1999. Concrete using waste oil palm shells as aggregate, Cement and Concrete Research 29(4): 619-622.

http://dx.doi.org/10.1016/S0008-8846(98)00233-6

BS EN 12390: Part 2. Testing hardened concrete-Making and curing specimens for strength tests. British Standard Institution, 2000.

BS EN 12390: Part 3. Testing hardened concrete- Compressive strength of test specimens. British Standard Institution, 2000.
Cachim, P. B.; Figueiras, J. A.; Pereira, P. A. A. 2002. Fatigue behavior of fiber-reinforced concrete in compression, $\mathrm{Ce}$ ment and Concrete Composites 24(2): 211-217. http://dx.doi.org/10.1016/S0958-9465(01)00019-1

Deeb, R.; Ghanbari, A.; Karihaloo, B. L. 2012. Development of self-compacting high and ultra high performance concretes with and without fibres, Cement and Concrete Composites 34(2): 185-190. http://dx.doi.org/10.1016/j.cemconcomp.2011.11.001

Düzgün, O. A.; Gül, R.; Aydin, C. 2005. Effect of steel fibers on the mechanical properties of natural lightweight aggregate concrete, Materials Letters 59(27): 3357-3363. http://dx.doi.org/10.1016/j.matlet.2005.05.071

Eren, Ö.; Çelik, T. 1997. Effect of silica fume and steel fibers on some properties of high-strength concrete, Construction and Building Materials 11(7-8): 373-382. http://dx.doi.org/10.1016/S0950-0618(97)00058-5

Fike, R.; Kodur, V. 2011. Enhancing the fire resistance of composite floor assemblies through the use of steel fiber reinforced concrete, Engineering Structures 33(10): 2870 2878. http://dx.doi.org/10.1016/j.engstruct.2011.06.011

Foo, K. Y.; Hameed, B. H. 2009. Value-added utilization of oil palm ash: a superior recycling of the industrial agricultural waste, Journal of Hazardous Materials 172(2-3): 523-531.

http://dx.doi.org/10.1016/j.jhazmat.2009.07.091

Gao, J. M.; Sun, W.; Morino, K. 1997. Mechanical properties of steel fiber-reinforced, high-strength, lightweight concrete, Cement and Concrete Composites 19(4): 307-313. http://dx.doi.org/10.1016/S0958-9465(97)00023-1

Habel, K.; Gauvreau, P. 2008. Response of ultra-high performance concrete fiber-reinforced concrete (UHPFRC) to impact and static loading, Cement and Concrete Composites 30(10): 938-946. http://dx.doi.org/10.1016/j.cemconcomp.2008.09.001

Jumaat, M. Z.; Alengaram, U. J.; Mahmud, H. 2009. Shear strength of oil palm shell foamed concrete beams, Materials and Design 30(6): 2227-2236. http://dx.doi.org/10.1016/j.matdes.2008.09.024

Kayali, O.; Haque, M. N.; Zhu, B. 2003. Some characteristics of high strength fiber reinforced lightweight aggregate concrete, Cement and Concrete Composites 25(2): 207213. http://dx.doi.org/10.1016/S0958-9465(02)00016-1

Kim, D. J.; Park, S. H.; Ryu, G. S.; Koh, K. T. 2011. Comparative flexural behaviour of Hybrid Ultra High Performance Fiber Reinforced Concrete with different macro fibers, Construction and Building Materials 25(11): 4144-4155. http://dx.doi.org/10.1016/j.conbuildmat.2011.04.051

Leslie, J. R.; Chessman, W. J. 1949. An ultrasonic method of studying deterioration and cracking in concrete structures, Journal of American Concrete Institute 21(1): 17-35.

Libre, N. A.; Shekarchi, M.; Mahoutian, M.; Soroushian, P. 2011. Mechanical properties of hybrid fiber reinforced lightweight aggregate concrete made with natural pumice, Construction and Building Materials 25(5): 2458-2464. http://dx.doi.org/10.1016/j.conbuildmat.2010.11.058

Mannan, M. A.; Ganapathy, C. 2001. Mix design for oil palm shell concrete, Cement and Concrete Research 31(9): 1323-1325.

http://dx.doi.org/10.1016/S0008-8846(01)00585-3

Mannan, M. A.; Ganapathy, C. 2002. Engineering properties of concrete with oil palm shell as coarse aggregate, Construction and Building Materials 16(1): 29-34. http://dx.doi.org/10.1016/S0950-0618(01)00030-7

Mannan, M. A.; Ganapathy, C. 2004. Concrete from an agricultural waste-oil palm shell (OPS), Building and Environment 39(4): 441-448.

http://dx.doi.org/10.1016/j.buildenv.2003.10.007 
Mannan, M. A.; Alexander, J.; Ganapathy, C.; Teo, D. C. L. 2006. Quality improvement of oil palm shell (OPS) as coarse aggregate in lightweight concrete, Building and Environment 41(9): 1239-1242. http://dx.doi.org/10.1016/j.buildenv.2005.05.018

Nataraja, M. C.; Dhang, N. Gupta, A. P. 2000. Toughness characterization of steel fiber-reinforced concrete by JSCE approach, Cement and Concrete Research 30(4): 593-597. http://dx.doi.org/10.1016/S0008-8846(00)00212-X

Newman, J.; Owens, P. 2003. Properties of lightweight concrete, advanced concrete technology set. Oxford: Butterworth-Heinemann. 1920 p.

Nili, M.; Afroughsabet, V. 2010. Combined effect of silica fume and steel fibers on the impact resistance and mechanical properties of concrete, International Journal of Impact Engineering 37(8): 879-886. http://dx.doi.org/10.1016/j.ijimpeng.2010.03.004

Nili, M.; Afroughsabet, V. 2012. Property assessment of steelfibre reinforced concrete made with silica fume, Construction and Building Materials 28(1): 664-669. http://dx.doi.org/10.1016/j.conbuildmat.2011.10.027

Okafor, F. O. 1988. Palm kernel shell as a lightweight aggregate for concrete, Cement and Concrete Research 18(6): 901910. http://dx.doi.org/10.1016/0008-8846(88)90026-9

Okay, F.; Engin, S. 2012. Torsional behavior of steel fiber reinforced concrete beams, Construction and Building Materials 28(1): 269-275.

http://dx.doi.org/10.1016/j.conbuildmat.2011.08.062
Özcan, D. M.; Bayraktar, A.; Sahin, A.; Haktanir, T.; Türker, T. 2009. Experimental and finite element analysis on the steel fiber-reinforced concrete (SFRC) beams ultimate behaviours, Construction and Building Materials 23(2): 1064-1077. http://dx.doi.org/10.1016/j.conbuildmat.2008.05.010

Shafigh, P.; Jumaat, M. Z.; Mahmud, H. 2010. Mix design and mechanical properties of oil palm shell lightweight aggregate concrete: a review, International Journal of Physical Science 5(14): 2127-2134.

Shafigh, P.; Mahmud, H.; Jumaat, M. Z. 2011. Effect of steel fiber on the mechanical properties of oil palm shell lightweight concrete, Materials and Design 32(7): 3926-3932. http://dx.doi.org/10.1016/j.matdes.2011.02.055

Short, A.; Kinniburgh, W. 1978. Lightweight concrete. $3^{\text {rd }}$ ed. London: Applied Science Publishers. 464 p.

Slater, E.; Moni, M.; Alam, A. S. 2012. Predicting the shear strength of steel fiber reinforced concrete beams, Construction and Building Materials 26(1): 423-436. http://dx.doi.org/10.1016/j.conbuildmat.2011.06.042

Teo, D. C. L.; Mannan, M. A.; Kurian, V. J.; Ganapathy, C. 2007. Lightweight concrete made from oil palm shell (OPS): structural bond and durability properties, Building and Environment 42(7): 2614-2621. http://dx.doi.org/10.1016/j.buildenv.2006.06.013

Yildiz, S.; Emiroğlu, M.; Atalar, O. 2012. Apricot pip shells used as aggregate replacement, Journal of Civil Engineering and Management 18(3): 318-322. http://dx.doi.org/10.3846/13923730.2012.698891

Soon Poh YAP. PhD Research Scholar at the Department of Civil Engineering of the University of Malaya, Malaysia. His main research interests include fibre-reinforced concrete, sustainable concrete materials and structural behaviour.

U. Johnson ALENGARAM. Senior Lecturer at the Department of Civil Engineering of the University of Malaya, Malaysia. His research interests include sustainable materials, lightweight concrete, fibre-reinforced concrete, geopolymer concrete, functional and structural behaviour.

Mohd. Zamin JUMAAT. Professor and Head of Department of the Department of Civil Engineering, University of Malaya, Malaysia. His research interests include reinforced concrete, structural performance of steel and timber in structural members and strengthening of beams in flexure and shear. 